\title{
Exploration and Practice about Informatization Construction of Teaching in Landscape Planning and Design
}

\author{
Yanglin Gao \\ Guangdong Industry of Polytechnic \\ Guangzhou, Guangdong, China 510300
}

\author{
$\mathrm{Lu} \mathrm{Yu*}$ \\ Guangzhou Vocational College of Science and Technology, \\ Guangzhou, Guangdong, China 510300
}

maximize the efficiency and effect of the teaching and practice within a limited time.

\begin{abstract}
This paper puts forward the purpose and principle of course informatization construction, and defines the frame and characteristics of informatization according to the characteristics of landscape planning and design course. On this basis, an informatization-based innovation practice teaching platform is built for landscape planning and design, including five modules and total 13 sub-items, and the construction of the course informatization brings a significant improvement to the teaching effect.
\end{abstract}

Keywords-landscape planning and design; teaching; informatization

\section{INTRODUCTION}

Informatization represents an ideal state where information technology is highly applied and information resources are highly shared, making human intelligent potentials and social material resource potential fully exerted and making individual behaviors, organizational decisions and social operations tend to rationalization. The Informatization can bring a powerful push for the productivity, promote the upgrading of traditional industries and greatly change people's work and learning patterns. At present, China is promoting the reform and innovation of vocational education through education informatization, the State Council has put forward a series of concepts such as "promote the extensive, deep and effective application of information technology to vocational education", "comprehensively strengthen the information technology to support the reform and development of vocational education, adopt advanced educational technologies to rebuild traditional education and teaching, and modernize the vocational education through informatization" and so on. As a core course of landscape engineering technology major, the landscape planning and design is extremely practical and in wide involvements, being an important field in the major [2]. The course teaching is closely related to practice, on the basis of theoretical teaching, a large number of practical design trainings are arranged to improve students' professional quality, enabling them to access to the demands of enterprises at a zero distance. Through the deep integration of the course teaching and practice and information technology, this article is to

Fund Project: Higher Vocational Education and Teaching Reform Project Project No: 201401043

*Corresponding author: $\mathrm{Lu} \mathrm{Yu}$

\section{PURPOSE AND PRINCIPLE FOR CONSTRUCTION OF COURSE INFORMATIZATION}

The main purpose of course informatization is to "improve teaching effect and efficiency", that is, informatization-related concept, means and methods are introduced to the teaching, complete more course contents and obtain higher learning quality within the same time as that in traditional teaching, so as to raise the teaching effect and efficiency, achieving the optimization in learning method, teaching mode and practice. After unceasing exploitation in teaching, according to the practice and feedback of informatization teaching, the principles for course informatization have been gradually made clear:

\section{A. Overall Coverage of the Learning Course}

The course informatization shall not be limited to the informatization of a few knowledge points, instead, the informatization should be fully integrated to class teaching, students' self-learning, project practice and so on, acting to serve and support the whole learning course.

\section{B. Highly Shared and Easy to Use}

The results of course informatization shall make it easy for teachers and students to access to and use. Even if the technologies used in informatization are relatively complex, but for end-users as teachers and students, the interaction shall be as simple and easy as to accept. It will minimize the costs in learning of information resources, allowing users to focus more energy on the results of informatization.

\section{Continuous Content Renewal}

Each subject is in a continuous development and progress, and the course teaching should closely follow the forefront of disciplines and industries, and corresponding content informatization shall also be carried out simultaneously. The informatization is not a 'one-shot deal', but should be expanded and optimized continuously as per the course adjusted. 


\section{Make Full Use of Information Technologies as Per Characteristics of Courses}

Information technology is based on computers and network technologies, and the specific technical categories that it contains are very complex, in the process of informatization, the optimal technologies shall be selected on the basis of course contents so as to optimize the informatization. In addition, the interdisciplinary cooperation between disciplines and information technologies-related ones is also very important.

\section{E. Improve the Informatization Level for Students' Learning and Practice}

On the basis of the informatization of course teaching, it needs to further improve the information technology level related to student's majors, and put the information technology into learning, project practice and coming work so as to raise the students' comprehensive quality and competitiveness in employment.

\section{FRAMEWORK AND FEATURES FOR INFORMATIZATION OF LANDSCAPE PLANNING DESIGN COURSE}

Set up an "informatization-based innovation practice teaching platform for landscape planning and design" to achieve the informatization of landscape planning and design course (www.cnscape.com) (refer to "Fig. 1"), which is based on students' learning of landscape design, meeting requirements of progressive learning from $\mathrm{ABC}$ to independent completion of medium and small-sized landscape design, and providing support for the whole-process learning covering learning in class and after class, practical training, project practice and external exchanges, etc. "Fig. 2"

The Platform takes "landscape design informatization learning module" as a core, "landscape major digital resource sharing module" and "online communication module" as supports, forming a digital teaching plate with internal and external exchanges, based on which, it builds a "landscape planning and design practice module", meeting the needs of major practice, innovation and startup and keeping a real-time connection with industries and markets. And ultimately expand the influence of this platform through the "external publicity display module", students and teachers will extend their field of vision to the forefront of the industries. The informatization of landscape planning and design course mainly highlights the following three features:

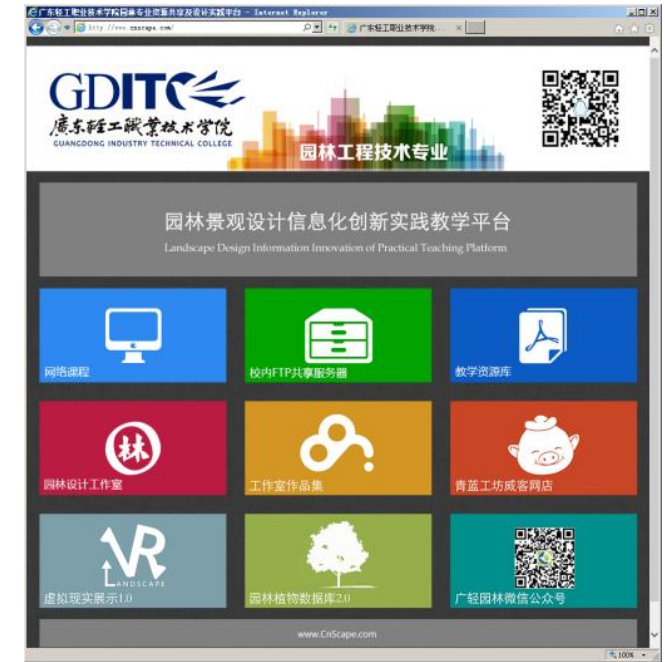

Fig. 1. Informatization-based innovation practice teaching platform for landscape planning and design

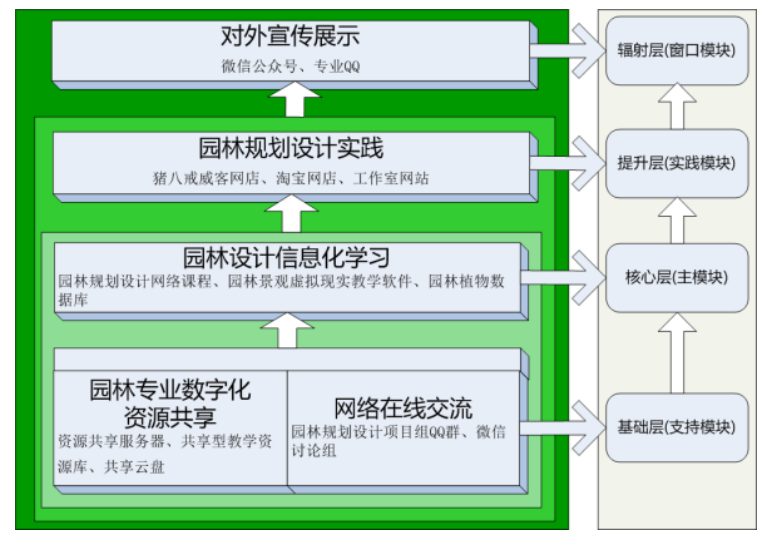

Fig. 2. Informatization system of landscape planning and design course

\section{A. Progressive Level in Content, Close to the Needs of Students}

The course informatization module is focused on the students' needs from initial entry to a school to graduation and stages in work. "Table I". It provides basic self-learning supports for the initial entry to a school to the practice improvement with certain professional capacities, covering the whole process of landscape design education.

TABLE I. DEEP INTEGRATION BETWEEN MODULES AND LEARNING STAGES

\begin{tabular}{|c|c|c|c|c|c|c|c|}
\hline Term & Term 1 & Term 2 & Term 3 & Term 4 & Term 5 & Term 6 & $\begin{array}{l}\text { Work after } \\
\text { Graduation }\end{array}$ \\
\hline $\begin{array}{l}\text { Learning stage } \\
\text { Informatization } \\
\text { module }\end{array}$ & $\begin{array}{l}\text { Introduction } \\
\text { to major }\end{array}$ & $\begin{array}{l}\text { Basic } \\
\text { knowledge } \\
\text { and skills }\end{array}$ & $\begin{array}{l}\text { Core } \\
\text { capabilities } \\
\text { of the major }\end{array}$ & $\begin{array}{l}\text { Upgrading of } \\
\text { comprehensive } \\
\text { capabilities }\end{array}$ & $\begin{array}{l}\text { Innovation } \\
\text { and Practice }\end{array}$ & $\begin{array}{l}\text { In-post } \\
\text { Practice }\end{array}$ & $\begin{array}{l}\text { Continued } \\
\text { Education }\end{array}$ \\
\hline \multicolumn{8}{|l|}{ Resource sharing } \\
\hline \multicolumn{8}{|l|}{ Online communication } \\
\hline \multicolumn{8}{|l|}{ Informatization learning } \\
\hline \multicolumn{8}{|l|}{ Design practice } \\
\hline Publicity and display & & & & & & & \\
\hline
\end{tabular}




\section{B. Beyond the Limit in Time and Space}

Computers and network technologies make the learning no longer be limited to classrooms or face to face teaching by teachers, and the introduction of micro-lecture and flipped classroom make it easy for students owning computers or smart phones to access to all of the course contents. Especially the virtual reality teaching software and technologies may help the practical training of landscape construction engineering to get rid of the troubles of failing to carry out or exercise design program due to excessive investment, so that the students can have opportunities for verification or practice in virtual spaces.

\section{Trans-Standalone and Network Systematic Teaching Platform}

The course informatization is not limited to standalone or network (Refer to "Table II"), instead, according to the actual needs of students and technical characteristics of development platforms, it will make a comprehensive use of the Internet and information technology to build a supporting system for leaning and work of the whole process of landscape design via micro innovation.

TABLE II. ITEM TYPE AND SERVICE ORIENTATION

\begin{tabular}{|c|c|c|c|c|c|}
\hline \multirow{2}{*}{ Standalone } & \multirow{2}{*}{ LAN } & \multicolumn{4}{|c|}{ Internet } \\
\hline & & Teaching & Practice & Publicity & Exchange \\
\hline $\begin{array}{l}\text { Virtual } \\
\text { reality } \\
\text { teaching } \\
\text { software of } \\
\text { landscape } \\
\text { design } \\
\text { (serve } \\
\text { teaching) }\end{array}$ & $\begin{array}{l}\text { Sharing } \\
\text { service of } \\
\text { landscape } \\
\text { resources } \\
\text { (serve } \\
\text { teaching } \\
\text { and } \\
\text { practice) }\end{array}$ & $\begin{array}{l}\text { Landscape } \\
\text { planning } \\
\text { and design } \\
\text { online } \\
\text { course, } \\
\text { landscape } \\
\text { plant } \\
\text { database, } \\
\text { landscape } \\
\text { resource } \\
\text { sharing } \\
\text { teaching } \\
\text { library, } \\
\text { shared } \\
\text { cloud }\end{array}$ & $\begin{array}{l}\text { Studios } \\
\text { websites, } \\
\text { ZBJ } \\
\text { stores, } \\
\text { Taobao } \\
\text { stores }\end{array}$ & $\begin{array}{l}\text { Major } \\
\text { WeChat } \\
\text { public } \\
\text { platform } \\
\text { account, } \\
\text { QQ }\end{array}$ & $\begin{array}{l}\text { Landscape } \\
\text { planning } \\
\text { and design } \\
\text { group QQ } \\
\text { group, } \\
\text { WeChat } \\
\text { discussion } \\
\text { group }\end{array}$ \\
\hline
\end{tabular}

\section{CONSTRUCTION AND USE OF INFORMATIZATION CONTENTS}

According to functions and needs of modules in the informatization system of landscape planning and design course, five modules, totally 13 sub-items, have been developed or established since 2010, and the details are given as follows:

\section{A. Landscape Design Informatization Learning Module}

1) Landscape planning and design online courses: including landscape planning and design, landscape design preliminary, landscape design creative practice and so on, 11 columns in total: teaching documents, course content, teaching courseware, electronic lesson plans, student design works, graduate works collection, programs collection, video library, learning references, material download and learning activities. "Fig. 3" According to the course progress, students may obtain course-related information synchronously in order for enquiry and self learning after class.

2) Landscape plant database: According to needs of students in landscaping of landscape plants for learning, develop an online database of the commonly used landscape plants [3] (refer to "Fig. 4"), containing data of more than 300 kinds of common landscape plants, able to seek for special information or browse as per class, family and category layer by layer, and students can enquire and use at anytime and anywhere.

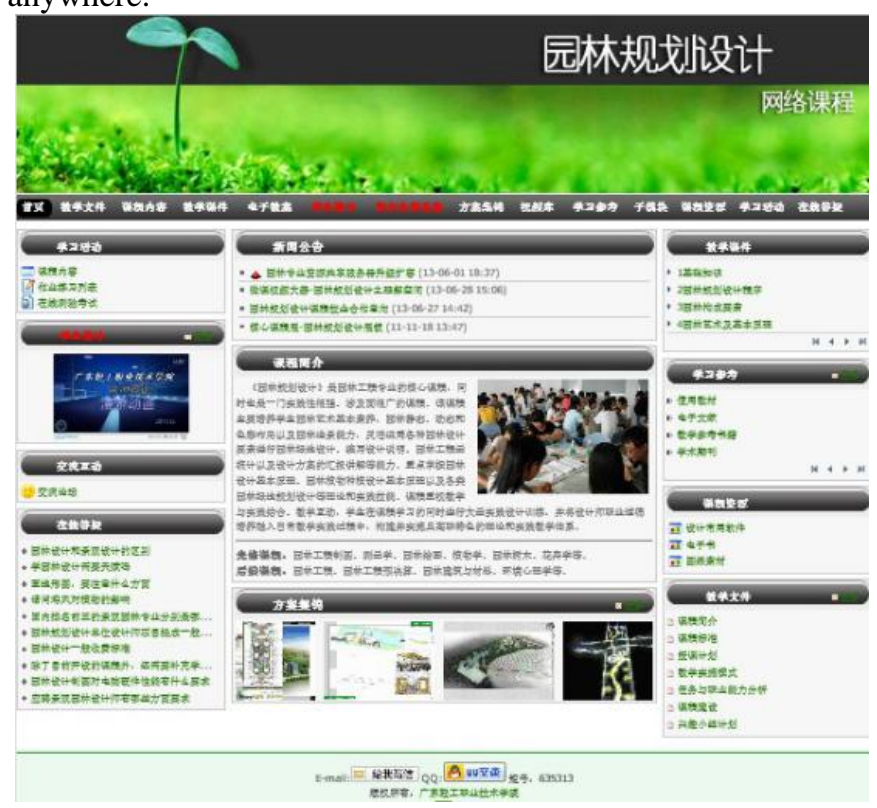

Fig. 3. Online landscape planning and design course

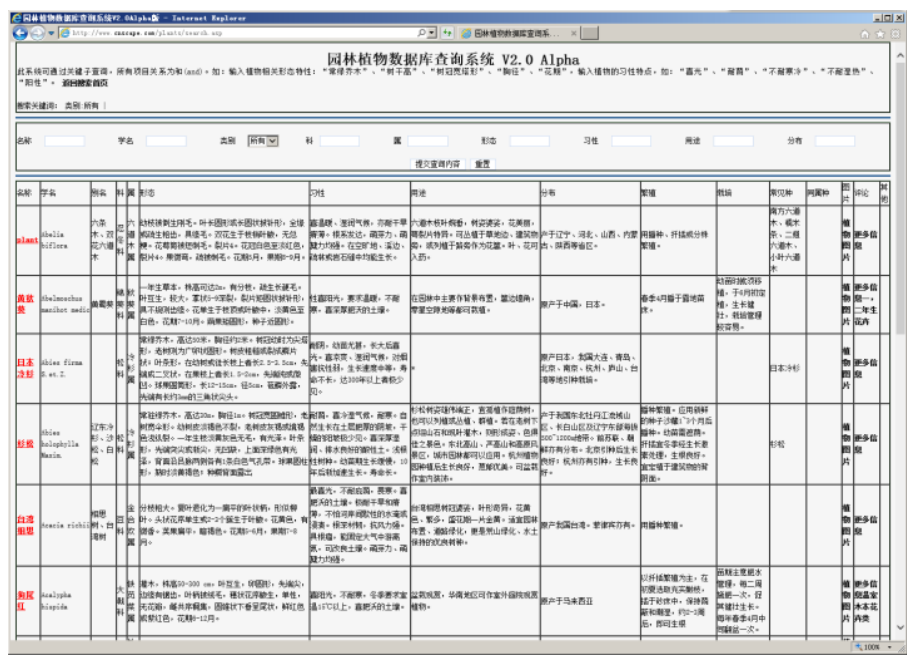

Fig. 4. Online landscape plants library

3) Landscape virtual reality teaching software: provide students with unity3d platform-based landscape virtual reality development paths, interactive display of landscape projects, virtual reality display of landscape elements construction, display of virtualized construction of landscape architectures, and so on (refer to "Fig. 5"), including 6 kinds and 25 typical 
construction scenes of landscape factors such as pavement, masonry, garden and water features[4][5]. Besides, students can also use the virtual reality technology to convert the design works of their own to interactive scenes, so as to fully optimize design programs for higher feasibility. Through the introduction of virtual reality technology and teaching software, it can not only achieve the students-based two-way flow of information in teaching and performance, but also to make up for the deficiencies in teaching conditions and site.

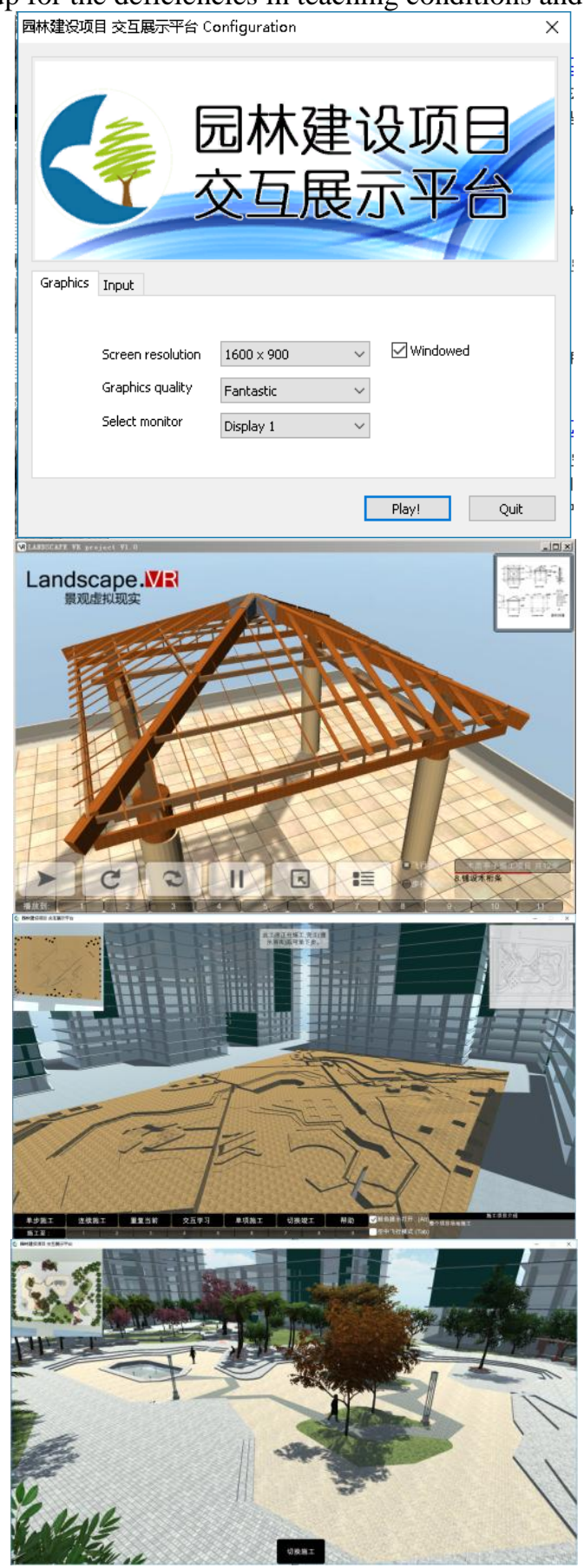

Fig. 5. Landscape virtual reality teaching software

\section{B. Digitalized Resource Sharing Module}

1) Resource sharing service: provide all-sided service for course teaching, design project practice and students' self learning. Both part-time and full-time teachers and schoolenterprise cooperative enterprises will collect course-related resources, current the resources total nearly $2 \mathrm{~TB}$ (refer to "Fig. 6", "Fig. 7"), including e-books, design materials, landscape design programs, teaching videos, landscape construction plans, commonly used design software, tutorials, a large number of major courses- related data as well as design practice project documents. $7 * 24$-hour services available online, students can access to all types of resources at any time, both inside and outside the school. Relying on the resource sharing services, the average monthly download flow reaches $2500 \mathrm{G}$, the average monthly visits reach 2,000 people or times, the service has become an important support for students' daily learning. In addition, in order to ensure the sustainable expansion of resources, open the rights of graduates for uploading resources, the graduates of early years can not only use the resources the same as those studying in the school, but also upload the high-quality resources of their own to share, and thus form a benign expansion of resources, currently the monthly uploading reaches about $20 \mathrm{G}$.

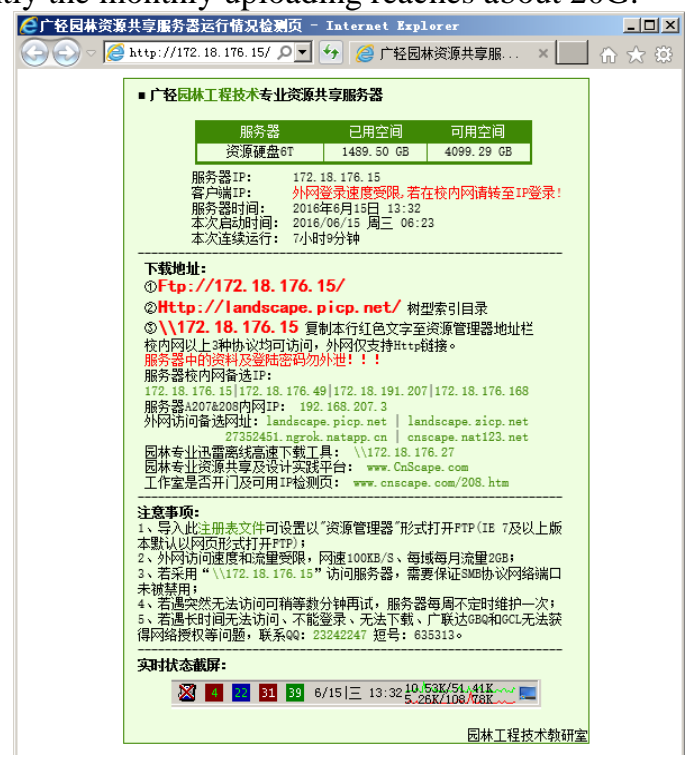

Fig. 6. Home of resource sharing service 


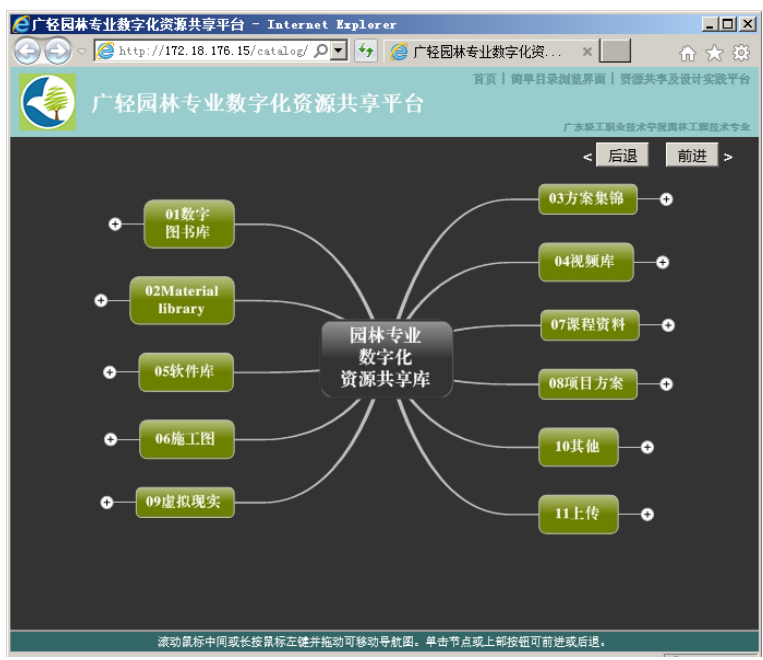

Fig. 7. Guide of resource service sharing

2) Shared teaching resource library and cloud sharing: Through the teaching resources platform under a unified planning and Baidu cloud platform, share course core teaching resources and information, and keep a real-time synchronization with the resource sharing service, making resource use more wider to cover and more convenient for graduates and cooperative enterprises to use online outside schools.

\section{Online Exchange Module}

In order to improve the efficiency and quality of students' design project in practice and communication, it needs to build landscape planning and design project group QQ group and WeChat discussion group. The online communication platform can not only extend the communication channels between teachers and students to facilitate teachers to track the progress and quality of design projects in real time, but also strengthen the contacts between students learning in the school and those who have graduated and provide students with real-time and open chances for communication.

\section{Landscape Planning and Design Practice Module}

In order to enhance the overall professional quality of students, and closely combine practical teaching and forefront development, it needs to set up websites as "ZBJ Witkey Stores", "Taobao Stores" and "Landscape Design Studio Website", through the online platforms, students can undertake real landscape design projects, based on the project acceptance, design and communication in a real work atmosphere, students will be promoted as early as possible to shift the role from students to designers and to regulate and standardize the designing and drawings, improve students' team collaboration and work efficiency and create favorable conditions for school-enterprise cooperation.

\section{E. External Publicity and Display Module}

Build a course-based WeChat public platform account (gqyuanlin) and post students' excellent works, design project works to share, raise the fame of majors and students' design studio and enhance the sense of presence of majors and courses in the industry. In addition, build a students' studio QQ (gdyuanlin@qq.com) for unified image publicity, and raise students' comprehensive quality and abilities in business communication and project undertaking.

\section{CONSTRUCTION EFFECT AND CONCLUSION}

Relying on the informatization mentioned above, the landscape planning and design course teaching has achieved the informatization in all aspects, greatly improving the teaching effect and efficiency, and the course teaching practice has made great achievements. In recent three years, the students-based design project teams have completed tens of landscape design projects, and the graduates of this major are widely welcome by enterprises. After participating in competitions of landscape design related vocational skills and students' challenge cup and so on, the students have won 7 awards at state-level and provincial level, and the course also won the first prize of provincial-level education software evaluation and the second prize of informatization teaching. With the joint advancement in teaching reform and informatization construction as well as the unceasing efforts of major teachers, the landscape engineering and technology major of our college has become a key and high level major built at the provincial level, and the teaching team become a higher vocational teaching team at the provincial level.

The course informatization plays a significant role in improving the teaching quality, but it is essential to optimize and upgrade the modern vocational education and teaching models on the basis of course informatization. That is, build design teams as landscape design studio run in an enterprise mode on the basis of students, carry out a large number of real project training, enrich students' work experience, strengthen their professional skills, making their overall quality connect with the future posts at a zero distance. In this process, it shall give a full play to the strength of information technology and integrate the concept of informatization in all aspects so as to achieve better effect in talent cultivation.

\section{REFERENCES}

[1] Baidu library. Informatization [DB/OL] http://baike.baidu.com/link?url=P23aszFxJEMhZfsGfQwqL0oNvhYGj ZsCtIFCtXvrolvwc76_MTG_UhAvtfq40fN46_bKa461IeI8cClGT1g3cc x-Polvr-HFV64aRELYM9apUL2qUjocPWQMChuaZLlf, 2015.7.

[2] Sha Ren Tu Ya, Analysis of Efficient Teaching of Landscape Planning and Design in Higher Vocational Colleges [J]. Journal of Inner Mongolia Normal University, 2015.9.

[3] Xu Jie, Analysis of Landscape Plant Morphology and Research on Landscape Application, Henan Agricultural University, 2013.

[4] Unity Technologies. Unity Manual[DB/OL]. http://docs.unity3d.com/, 2014.8.

[5] Unity Technologies. Unity 4.X, From ABC to proficiency [M]. China Railway Publishing House, 2013. 